\title{
Średniowieczne pieczęcie konwentu z klasztoru cysterskiego w Lubiążu - chronologia, ikonografia i kwestia autorstwa typariuszy*
}

Pamięci Franciszki Kramarz z domu Myrdak (1925-2020)

Zarys treści: $\mathrm{W}$ artykule przedstawiono analizę ikonografii dwóch pieczęci konwentu lubiąskiego wykonanych w pierwszej połowie XIV w., a także źródła inspiracji obrazu pieczęci. Wskazano następnie prawdopodobne przyczyny wymiany typariuszy między 1341 a $1343 \mathrm{r}$. Uwagę poświęcono ponadto autorstwu pieczęci konwentu lubiąskiego.

\begin{abstract}
The article presents an analysis of the iconography of two convent seals of Lubiąż made in the first half of the fourteenth century and the sources of inspiration for the seal images. Then, it indicates the probable reasons for the exchange of the seal matrices between 1341 and 1343. Attention is also paid to the authorship of the convent seals of Lubiąż.
\end{abstract}

Słowa kluczowe: pieczęcie konwentu, cystersi, Lubiąż, Śląsk, sfragistyka kościelna

Keywords: convent seals, Cistercians, Lubiąż (Leubus), Silesia, ecclesiastical sigillography

Sfragistyka klasztoru cysterskiego w Lubiążu jest jedną z lepiej opracowanych na tle innych opactw tego zakonu. Już w pracach z drugiej połowy XIX w. poświęconych pieczęciom śląskim pióra Alwina Schultza oraz Paula Pfotenhauera odnotowano lub podano bliższy opis pieczęci opatów lubiąskich z XIII i początku XIV w. ${ }^{1} \mathrm{~W}$ okresie międzywojennym Helene Krahmer, omawiając pieczęcie kościelne ze Śląska, w tym cysterskie, zwróciła uwagę na zastosowanie pieczęci opata lubiąskiego z pierwszej połowy XIII w. jako znaku przełożonego klasztoru². W tym samym czasie Marian Gumowski w pracy poświęconej pieczęciom książęcym, duchowieństwa, rycerstwa i miast z terenu Śląska opublikował gipsowy

\footnotetext{
* Pierwotna wersja niniejszego artykułu została wygłoszona podczas seminarium doktorskiego Profesor Marii Koczerskiej i Profesora Piotra Węcowskiego w Instytucie Historycznym Uniwersytetu Warszawskiego 10 I 2020. W tym miejscu dziękuję za dyskusję oraz cenne uwagi. Praca jest efektem realizacji projektu badawczego nr 2017/01/X/HS3/00268 finansowanego ze środków Narodowego Centrum Nauki w latach 2017-2018.

1 A. Schultz, Die schlesischen Siegel bis 1250, Breslau 1871, s. 13, Taf. VIII, nr 60-61; P. Pfotenhauer, Die schlesischen Siegel von 1250 bis 1300, beziehentlich 1327, Breslau 1879, s. 22.

${ }^{2}$ H. Krahmer, Beiträge zur Geschichte des geistlichen Siegels in Schlesien bis zum Jahre 1319, „Zeitschrift des Vereins für Geschichte Schlesiens", 69, 1935, s. 6-7, 30-31.
} 
odlew średniowiecznej pieczęci konwentu lubiąskiego wraz z opisem i odczytem legendy napieczętnej³. Krótka wzmianka o tej pieczęci pojawiła się również w rozdziale tego autora w podręczniku do sfragistyki z lat 60 . XX w. ${ }^{4}$ Franciszek Hanus w monografii opactwa lubiąskiego wydanej po II wojnie światowej treściwie omówił ikonografię pieczęci opatów do połowy XIV w., wraz z przytoczeniem legendy jednej z pieczęci. Opublikował też czarno-białe fotografie dokumentów oraz pieczęci opatów i konwentu lubiąskiego ${ }^{5}$. W latach 80. XX w. wiele artykułów poświęconych opactwom cysterskim na Śląsku ogłosił Heinrich Grüger. W pracy dotyczącej klasztoru w Lubiążu powtórzył jednakże ustalenia P. Pfotenhauera w kwestii pieczęci opatów; stwierdził również, że nie jest znana pieczęć konwentu lubiąskiego ${ }^{6}$. Był to zatem częściowy regres w badaniach nad sfragistyką lubiąską. Pierwszą pracą w większym stopniu opartą na materiałach archiwalnych był artykuł Przemysława Wiszewskiego. Autor ten przeanalizował późnośredniowieczne pieczęcie opatów lubiąskich, w tym ich pieczęć sekretną oraz pieczęć konwentu znaną już M. Gumowskiemu. Załączył też fotografie wybranych pieczęci ${ }^{7}$. W innym artykule zbadał on elementy przyrody występujące na średniowiecznych pieczęciach śląskich. Omówił pod tym kątem m.in. pieczęcie opatów oraz konwentu lubiąskiego ${ }^{8}$. Pieczęć konwentu została skrótowo opisana także w katalogu klasztorów cysterskich ${ }^{9}$. Marek L. Wójcik w artykule poświęconym heraldyce klasztorów cysterskich na Śląsku przedstawił wiele średniowiecznych i nowożytnych pieczęci opatów oraz trzy pieczęcie konwentu lubiąskiego ${ }^{10}$. Waldemar P. Könighaus w najnowszej monografii średniowiecznego klasztoru w Lubiążu zestawił natomiast listę opatów z danymi o ich pieczęciach. Zamieścił ponadto podstawowe informacje o zmianach zachodzących na pieczęciach opatów i pojawieniu się pieczęci konwentu w opactwie w pierwszej połowie XIV w. Dołączył także ilustracje wybranych pieczęci rządców klasztoru, ich sekretu, wójta klasztornego oraz konwentu ${ }^{11}$. Romuald Kaczmarek w rozważaniach poświęconych średniowiecznemu wyposażeniu i wystrojowi kościoła klasztornego w Lubiążu syntetycznie omówił pieczęcie opatów lubiąskich oraz pieczęć konwentu. Dodał też krótkie uwagi o miejscu wykonania tłoków klasztornych ${ }^{12}$. Beata Marcisz-Czapla w katalogu poświęconym rzemiosłu sakralnemu zamieściła edycję pieczęci cystersów ze Śląska znajdujących się w zbiorach Muzeum Narodowego we Wrocławiu, opatrując niektóre z nich fotografiami. Omówiła m.in. nowożytne pieczęcie opatów lubiąskich, a także prowizoratu, prepozytury w Kazimierzu oraz średniowieczną pieczęć konwentu zachowaną w odciskach ${ }^{13}$. Artur Hryniewicz wymienił natomiast m.in. zaginione nowożytne typariusze opata

\footnotetext{
${ }^{3}$ M. Gumowski, Pieczęcie śląskie do końca XIV wieku, w: Historia Śląska od najdawniejszych czasów do roku 1400, t. 3, red. W. Semkowicz, Kraków 1936, s. 319, tabl. 119, nr 95, s. 435.

${ }^{4}$ Tenże, Sfragistyka polska, w: M. Gumowski, M. Haisig, S. Mikucki, Sfragistyka, Warszawa 1960, s. 218.

${ }^{5}$ F. Hanus, Die aeltere Geschichte der Zisterzienser - Abtei Leubus in Schlesien bis zur Mitte des 14. Jahrhunderts, Teutopolis 1947, s. 117 oraz ilustracje pieczęci opackich i konwentu.

${ }^{6}$ H. Grüger, Leubus. Zisterzienserabtei, „Jahrbuch der Schlesischen Friedrich-Wilhelms-Universität zu Breslau”, 22, 1981 , s. 28.

${ }^{7}$ P. Wiszewski, Średniowieczna śląska pieczęć klasztorna jako środek przekazu informacji (XIII - 1 połowa XVI w.), w: Pieczęć w Polsce średniowiecznej i nowożytnej, red. P. Dymmel, Lublin 1998, s. 11-29.

${ }^{8}$ Tenże, Elementy natury na wizerunkach wybranych średniowiecznych pieczęci ślaskich, w: Człowiek i przyroda w średniowieczu $i$ we wczesnym okresie nowożytnym, red. W. Iwańczak, K. Bracha, Warszawa 2000, s. 78-83.

9 A. Harc, L. Harc, E. Łużyniecka, Lubiąz, w: Monasticon Cisterciense Poloniae, t. 2, red. A.M. Wyrwa, J. Strzelczyk, K. Kaczmarek, Poznań 1999, s. 209.

${ }^{10}$ M.L. Wójcik, Heraldyka klasztorów cysterskich na Ślasku, w: Polska heraldyka kościelna. Stan i perspektywy badań, red. K. Skupieński, A. Weiss, Warszawa 2004, s. 43-58.

11 W.P. Könighaus, Die Zisterzienserabtei Leubus in Schlesien von ihrer Gründung bis zum Ende des 15. Jahrhunderts, Wiesbaden 2004, s. 92, 358-375, 407-412.

12 R. Kaczmarek, Średniowieczne elementy wyposażenia i wystroju kościoła klasztornego Wniebowzięcia NMP w Lubiążu. Próba rekonstrukcji, w: Kościót klasztorny Wniebowzięcia NMP w Lubiąż. Historia, stan zachowania, koncepcja rewitalizacji, red. A. Kozieł, Wrocław 2010, s. 54.

${ }^{13}$ B. Marcisz-Czapla, Tłoki pieczętne i pieczęcie kościelne z terenu Śląska, w: Gloria Deo. Rzemiosło sakralne, t. 2, red. M. Korżel-Kraśna, Wrocław 2010, s. 110-116. W artykule wydanym kilka lat później autorka zestawiła w formie tabeli publikowane już wcześniej pieczęcie cysterskie, w tym z Lubiąża; zob. taż, Tłoki pieczętne z sekularyzowanych klasztorów śląskich w zbiorach Muzeum Narodowego we Wrocławiu, w: Kasaty klasztorów na obszarze dawnej Rzeczypospolitej Obojga Narodów i na Śląsku na tle procesów sekularyzacyjnych w Europie, t. 3, red. M. Derwich, Wrocław 2014, s. 299.
} 
lubiąskiego i prepozytury w Kazimierzu oraz średniowieczny tłok konwentu ${ }^{14}$. Autor niniejszego tekstu w ostatnich latach omówił m.in. ikonografię średniowiecznych pieczęci cystersów śląskich, w tym opatów lubiąskich, a oddzielne studium poświęcił analizie nowożytnych pieczęci opatów lubiąskich ${ }^{15}$.

Przedstawiony powyżej przegląd badań wskazuje, że sfragistyka klasztoru lubiąskiego jest nadal nierównomiernie opracowana. Najlepiej rozpoznane zostały pieczęcie opatów. Na temat innych pieczęci, w tym konwentu, posiadamy niepełne i rozproszone informacje. Niniejszy artykuł stawia sobie za cel przede wszystkim uporządkowanie danych na temat najstarszych pieczęci lubiąskiego konwentu. Należy zatem rozważyć, czy konwent posługiwał się w średniowieczu tylko jedną pieczęcią, czy też zlecił wykonanie jeszcze innego tłoka, a jeżeli tak, to jaka była chronologia wprowadzania ich do użycia. Następnie przedstawiona zostanie ikonografia pieczęci konwentu, w tym problem transferu wizerunku (konkretnego tematu ikonograficznego). Wskazanie źródeł inspiracji pozwala odpowiedzieć na pytanie, czy przy wyborze wyobrażeń napieczętnych cystersi korzystali z rozwiązań ikonograficznych wprowadzanych w ich klasztorach macierzystych (na podstawie kontaktów międzyregionalnych, do których dochodziło podczas obrad kapituły generalnej w Cîteaux), czy też stosowali innowacje czerpiące z lokalnych uwarunkowań ${ }^{16}$. Należy również zastanowić się nad przyczynami wprowadzenia na pieczęcie konkretnego tematu ikonograficznego. Kwestie dotyczące ikonografii oraz cech formalno-stylistycznych pieczęci umożliwiają natomiast podjęcie problematyki dotyczącej autorstwa typariuszy.

\section{Jedna czy dwie pieczęcie konwentu lubiąskiego w średniowieczu?}

W większości wymienionych wcześniej opracowań wielokrotnie przywoływana była jedna średniowieczna pieczęć konwentu z Lubiąża. Poza ogólnym jej omówieniem i wskazaniem na podobieństwa z miniaturą z lubiąskiego kodeksu nie przyjrzano się bliżej okolicznościom wprowadzenia tej pieczęci do użycia. Powoływano się przy tym na egzemplarze tej pieczęci z $1343 \mathrm{r} \cdot{ }^{17}$ Tymczasem w monografii klasztoru lubiąskiego autorstwa W.P. Könighausa podano dwie istotne informacje: autor opublikował fotografię pieczęci konwentu z adnotacją o stosowaniu jej od 1343 r. i wskazał, że pieczęć jest uchwytna źródłowo od $1341 \mathrm{r}^{18} \mathrm{~W}$ tej kwestii powołał się na regest dokumentu zamieszczony w znanym wydawnictwie źródłowym Codex diplomaticus Silesiae ${ }^{19}$. Należało zatem postawić pytanie, czy mamy do czynienia z kolejnym odciskiem znanej już pieczęci, czy z inną pieczęcią. W pierwszej kolejności zwróciłem uwagę na ilustracje wymienionego dokumentu oraz pieczęci (opata i konwentu) z $1341 \mathrm{r}$. zamieszczone w powojennej monografii klasztoru lubiąskiego wspomnianego wcześniej F. Hanusa. Reprodukowana

14 A. Hryniewicz, Trzy inwentarze śląskich typariuszy posekularyzacyjnych, „Roczniki Sztuki Śląskiej”, 25, 2016, s. 251-252, 254; tenże, Wrocławska kolekcja zabytkowych tłoków pieczętnych, historia jej powstania i rozwoju oraz straty wojenne, „Roczniki Sztuki Śląskiej”, 27, 2018, s. 230-231.

15 T. Kałuski, Napisy na pieczęciach opatów z klasztorów cysterskich na Dolnym Śląsku w średniowieczu, „Sfragìstičnij ŝričnik", 6, 2016, s. 68-78; tenże, Imago abbatis na pieczęciach śląskich cystersów w średniowieczu, w: Dzieje i kultura cystersów w Polsce. 2, red. M. Starzyński, D. Tabor, Kraków 2018, s. 395-415, 665-667; tenże, Od przedstawień figuralnych do heraldycznych. Opaci lubiascy i ich pieczęcie od schyłku średniowiecza do sekularyzacji klasztoru w 1810 roku, St. Źródł., 57, 2019, s. 159-210.

${ }^{16}$ Zob. tenże, Obraz w stużbie mnichów. Średniowieczna pieczęć konwentu z opactwa cysterskiego w Krzeszowie, Sobótka, 73, 2018, nr 4, s. 147-161.

17 P. Wiszewski, Średniowieczna śląska pieczęć, s. 16; A. Harc, L. Harc, E. Łużyniecka, Lubiąż, s. 209; R. Kaczmarek, Średniowieczne elementy, s. 54. Ustalenia, za literaturą, dotyczące datacji pieczęci konwentu przyjęli następnie: P. Stróżyk, Pieczęcie cysterskie z opactwa w Łeknie-Wagrowcu (cz. I), „Studia i Materiały do Dziejów Pałuk”, 4, 2003, s. 187; M. Szymoniak, Średniowieczne pieczęcie cysterskie z diecezji krakowskiej jako źródło badań nad zakresem władzy opatów i konwentów, „Zeszyty Naukowe Towarzystwa Doktorantów Uniwersytetu Jagiellońskiego”, Nauki Społeczne, 9, 2014, z. 2, s. 172.

18 W.P. Könighaus, Die Zisterzienserabtei Leubus, s. 92, 407.

${ }^{19}$ Regesten zur Schlesischen Geschichte 1338-1342, wyd. K. Wutke, E. Randt, Codex diplomaticus Silesiae, t. 30, Breslau 1930, s. 173, nr 6619. 
tam pieczęć konwentu różniła się od tej z 1343 r. ${ }^{20}$ Przeprowadzona przeze mnie ponowna kwerenda archiwalna pozwoliła przyjąć, że przy dokumencie wystawionym przez opata Jana II z Legnicy w $1341 \mathrm{r}$. przywieszona została poza jego pieczęcią inna pieczęć konwentu ${ }^{21}$.

\section{Ikonografia pieczęci konwentu lubiąskiego}

Nie podlega dyskusji, że bezpośrednim impulsem, który sprawił, że konwenty cysterskie, w tym klasztor lubiąski, zaczęły posługiwać się własnymi pieczęciami, była bulla Fulgens sicut Stella Matutina papieża Benedykta XII z 12 VII 1335 oraz uchwała kapituły generalnej z tego roku. W bulli nakazano konwentom wykonać własne pieczęcie, a dokumenty opackie współpieczętować pieczęciami konwentów. Kapituła generalna powołała się na przestrzeganie jedności w zakonie i postanowienie papieskie co do posiadania pieczęci przez konwent oraz dodała dalsze szczegóły związane z tymi pieczęciami. Trzeba jednakże zaznaczyć, że część konwentów posługiwała się własną pieczęcią już przed tą datą. We wspomnianym statucie z 1335 r. wskazano przede wszystkim, że na wszystkich pieczęciach konwentów powinien zostać wyryty wizerunek Marii. Ujednolicono również zalecenia dotyczące kształtu i materiału pieczęci. Miały one mieć kształt okrągły oraz zostać wykonane z miedzii ${ }^{22}$. Nie wskazano przy tym czasu, w jakim miały być wprowadzone do użycia. Przypuszczać należy, że - podobnie jak w przypadku ustawodawstwa dotyczącego pieczęci opackich - miało to nastąpić w ciągu kilku miesięcy, a zatem prawdopodobnie do kolejnej kapituły w 1336 r. Nie jest niestety znany udział cystersów śląskich w kapitule z 1335 r. Informacje zachowały się dopiero z kolejnego roku. Najprawdopodobniej uczestniczył w niej tylko Henryk, przedstawiciel klasztoru kamienieckiego (bez podania funkcji), nie było tam opatów z innych klasztorów śląskich, w tym z Lubiąża ${ }^{23}$. Nie można jednak wykluczyć, że mnisi lubiąscy wkrótce po zebraniu kapituły we wrześniu 1335 r. zlecili wykonanie swojej pieczęci. Szybką reakcję konwentów cysterskich potwierdza np. pieczęć z brandenburskiego klasztoru w Himmelpfort, która zachowała się przy dokumencie z 25 XI $1335^{24}$.

Pierwsza pieczęć konwentu lubiąskiego znana jest z jednego odcisku przywieszonego na pasku pergaminowym przy wzmiankowanym powyżej dokumencie opata Jana II z Legnicy z 28 VI 1341 (zob. il. 1) ${ }^{25}$. Jest to pieczęć odciśnięta $\mathrm{w}$ wosku zielonym w misce $\mathrm{z}$ wosku naturalnego o średnicy $34 \mathrm{~mm}$. Współpieczętowano nią dokument wystawiony przez opata Jana II z Legnicy dotyczący sprzedaży ksieni

${ }^{20}$ F. Hanus, Die aeltere Geschichte, po s. 117.

${ }^{21}$ AP Wrocław, Rep. 125, nr 186 b.

${ }^{22}$ Constitutio Benedicti papae XII pro reformatione Ordinis Cisterciensis, w: Statuta Capitulorum Generalium Ordinis Cisterciensis ab anno 1116 ad annum 1786 [dalej: Statuta], t. 3: Ab anno 1262 ad annum 1400, wyd. J.-M. Canivez, Louvain 1935, s. 411, 415; tamże, 1335/nr 2. W literaturze przedmiotu omawiane zagadnienie zostało już przedstawione; zob. zwł.: G. Müller, Von den Siegeln im Orden, „Cistercienser Chronik”, 31, 1919, s. 5-7; T.A. Heslop, Cistercian Seals in England and Wales, w: Cistercian Art and Architecture in the British Isles, red. Ch. Norton, D. Park, Cambridge 1986, s. 266-283; D.H. Williams, The Cistercians in the Early Middle Ages, Leominster 1998, s. 109-111; T. Vogtherr, Siegelrecht, Siegelmißßrauch und Siegelfälschung bei den Zisterziensern, „Archiv für Diplomatik”, 45, 1999, s. 61-85; P. Stróżyk, Pieczęcie cysterskie, s. 179-202. Należy ponadto zauważyć, że w literaturze czasem błędnie przypisuje się bulli Benedykta XII wprowadzenie wizerunku maryjnego na pieczęciach konwentu oraz określenie kształtu i materiału typariuszy; zob. D. Stehlíková, Cistercian Seals in Bohemia and Moravia from 1220 to 1520, „Cîteaux. Commentarii cistercienses”, 47, 1996, s. 330; T. Krejčík, Pečet'v kultuře středověku, Ostrava 1998, s. 245; M. Glejtek, Ikonografia pečatí konventov a kapitúl $v$ stredovekom Uhorsku, w: Pontes ad fontes. Církevni dějiny ve světle pomocných věd historických a príbuzných oborů, red. M. Bolom-Kotari, V. Němečková, Hradec Králové 2011, s. 122-123, 127; tenże, Stredoveká cirkevná pečat'-pramen̆ krest'anskej ikonografie, Hradec Králové 2013, s. 127-128.

${ }^{23}$ A. Galar, W europejskiej wspólnocie cysterskiej. Udział cystersów z historycznych ziem polskich w Kapitułach Generalnych w Cîteaux (XII-XVIII w.), Kraków 2014, s. 220-221.

${ }^{24}$ Brandenburgisches Klosterbuch. Handbuch der Klöster, Stifte und Kommenden bis zur Mitte des 16. Jahrhunderts, t. 1, wyd. H.D. Heimann, K. Neitmann, W. Schich, M. Bauch, E. Franke, Ch. Gahlbeck, Ch. Popp, P. Riedel, Berlin-Brandenburg 2007, s. 617, 623. Rysunek pieczęci konwentu z błędami w odczycie legendy oraz niedokładnym przedstawieniem wyobrażenia i datacją tłoka zob. F.A. Vossberg, Die Siegel der Mark Brandenburg, t. 1, Berlin 1868, s. 19, Taf. E. 1.

25 AP Wrocław, Rep. 125, nr 186b. 
Jadwidze i konwentowi w Trzebnicy, za zgodą konwentu, zwierzchniego prawa oraz połowy sądownictwa sołeckiego we wsi Brodno ze wszystkim użytkami i przynależnościami. Pieczęć przedstawia tronującą Marię z Dzieciątkiem, mającą na głowie sfałdowany welon, na którym spoczywa korona. Maria w zgiętej prawej ręce dzierży jabłko. Jezus, stojący asymetrycznie na jednym z kolan Marii lub z boku na ławie tronowej, trzyma w lewej ręce jabłko, a prawą ręką, zwracając się w stronę Matki, wykonuje gest dotknięcia. Centralne figury umieszczono w gotyckiej arkadzie, po bokach której znajdują się edykuły z klęczącymi mnichami-adorantami. Po heraldycznie prawej stronie widoczny jest mnich trzymający świecę, a po lewej opat z pastorałem. Stan zachowania pieczęci pozwala również na rozważenie innej interpretacji wizerunków umieszczonych w edykułach. Można dopatrzeć się tam bowiem półfigur aniołów trzymających świece ${ }^{26}$. Przedstawienia postaci cechuje brak lekkości i finezji w ryciu tłoka. Jest to po części wynik skali pieczęci i stanu zachowania odcisku woskowego. Detal rzeźby pieczęci jest przez to pogrubiony. Legenda umieszczona w otoku w podwójnej obwódce perełkowej brzmi: $\mathrm{S}($ igillum $) \cdot \mathrm{COnVEnTVS} \bullet \mathrm{DE} \bullet \mathrm{LVBEnS}$. Została wykonana majuskułą gotycką z elementami uncjały.

Drugi tłok pieczęci konwentu jest poświadczony w użyciu po raz pierwszy przy trzech dokumentach z 14 IV 1343 wystawionych przez wymienionego wcześniej opata Jana. Przy wszystkich pieczęć o średnicy $50 \mathrm{~mm}$ została odciśnięta $\mathrm{w}$ wosku zielonym $\mathrm{w}$ miskach $\mathrm{z}$ wosku naturalnego i przywieszona na paskach pergaminowych (zob. il. 3). Pierwszy z dokumentów odnosi się do sprzedaży jatki w Wołowie, należącej do urzędu zakrystiana, i na przydzieleniu mu nowych źródeł dochodu ${ }^{27}$. W drugim dokumencie wskazano, że na mocy testamentu dochody z 2 łanów koło Jawora przeznaczone na utrzymanie kopistów ksiąg zostały następnie wykorzystane na inne cele ${ }^{28}$. Trzeci z dokumentów dotyczył przydzielenia konwentowi za zgodą starszych pitancji (dodatkowej porcji żywności) z fundacji księcia legnicko-brzeskiego Bolesława III ${ }^{29}$.

Drugi typ pieczęci konwentu wykonano zatem między drugą połową 1341 a początkiem kwietnia 1343 r. W przypadku cystersów, jak również innych wspólnot zakonnych, można zaobserwować „długie trwanie" użytkowanych tłoków. Pierwsza pieczęć była jednak stosowana przez krótki czas, co było nietypowym zjawiskiem. Typariusz drugiej pieczęci był już dowodnie stosowany do sekularyzacji klasztoru, gdyż jego najpóźniejszy znany odcisk zachował się przy dokumencie z 1793 r. ${ }^{30}$ Po sekularyzacji opactwa wraz z innymi tłokami został przewieziony do Wrocławia. Do schyłku XIX w. był przechowywany w tamtejszym Archiwum Państwowym. W wykazie tłoków skasowanych klasztorów, które zostały przekazane w formie depozytu do Muzeum Starożytności Śląskich w 1893 r. zawarto krótką charakterystykę typariusza. Z opisu dowiadujemy się, że płytka tłoka została wykonana ze srebra i opatrzona prawdopodobnie żelazną nasadką (Silberplatte auf Eisen) (zob. il. 5-6) ${ }^{31}$. Omawiany typariusz, zapewne ze względu na zastosowany materiał, zaginął po $1945 \mathrm{r}$.

Druga pieczęć konwentu pod względem ikonografii różni się od poprzedniej. W obrazie została ukazana Maria okrywająca płaszczem sześciu mnichów w typie Matki Miłosierdzia (Mater Misericordiae). Podobieństwa do poprzedniego sigillum dostrzegalne są tylko w zakresie mikroarchitektury. Centralne figury zostały bowiem umieszczone również w gotyckiej arkadzie wypełnionej w tym wypadku gwiazdami, a dwie postacie przedstawiono w edykułach. Po heraldycznie prawej stronie stojący mnich trzyma świecę, a po lewej ukazano klęczącego opata z pastorałem. Mnisi zostali ukazani w kukullach, u niektórych z nich można dostrzec kaptury. Marię przedstawiono w kontrapoście, jej sylwetka jest harmonijna, a fałdowania szat oraz welonu oddano wyjątkowo plastycznie. Poszczególne figury są przedstawione z dbałością o precyzję, którą można dostrzec w oddaniu fizjonomii twarzy niektórych zakonników.

\footnotetext{
${ }^{26} \mathrm{~W}$ tym miejscu składam podziękowanie jednemu z Recenzentów publikowanego tekstu za wskazanie na tę możliwość interpretacji.

27 AP Wrocław, Rep. 91, nr 290.

${ }^{28}$ Tamże, $\mathrm{nr} 291$.

29 Tamże, nr 292.

${ }^{30}$ AP Wrocław, Oddział Legnica, Dokumenty cechowe miasta Legnicy, sygn. 163.

31 AP Wrocław, Kolekcja rękopisów Oddziału I, sygn. 369. O przekazaniu typariuszy do wrocławskiego Muzeum zob. B. Krusch, Geschichte des Staatsarchivs zu Breslau, Leipzig 1908, s. 337; A. Hryniewicz, Wrocławska kolekcja, s. $230-231$.
} 
To wszystko pozwala uznać omawianą pieczęć za jeden ze wspanialszych przykładów śląskiego rzemiosła artystycznego okresu gotyku. Legendzie umieszczonej w otoku w podwójnej obwódce perełkowej nadano brzmienie: S(igillum) $・$ COnVEnTVS • / MOn(asterii) $・$ DE $・$ LVBEnS. Inskrypcja została wykonana, tak samo jak poprzednia, majuskułą gotycką z elementami uncjały.

Wizerunek tronującej Marii z Dzieciątkiem (Maiestas Mariae oraz w wersji Sedes Sapientiae) był rozpowszechniony w sztuce średniowiecznej zarówno w formie rzeźb, jak i obrazów ${ }^{32}$, a w kręgu cysterskim znany jest od drugiej połowy XII w. ${ }^{33}$, w tym na pieczęciach klasztornych i konwentualnych ${ }^{34}$. Należy zatem zastanowić się, jakie wyobrażenie mogło stać się inspiracją do wykonania pierwszej pieczęci konwentu lubiąskiego. Najbardziej naturalne jest uwzględnienie pieczęci konwentualnej protoopactwa w Morimond ${ }^{35}$ oraz macierzy w Pforcie ${ }^{36}$. Tronująca Madonna na tych pieczęciach odbiega jednak od wizerunku lubiąskiego. Rozwiązania należy poszukiwać zatem gdzie indziej. Mnisi mogli znać rzeźbę tronującej Marii z Dzieciątkiem powstałą około połowy XIII w., która pochodziła z macierzystego kościoła klasztornego w Pforcie ${ }^{37}$. Jest ona jednak odmienna od wizerunku napieczętnego pierwszej pieczęci konwentu. Ze średniowiecznego wyposażenia kościoła klasztornego w Lubiążu niewiele się zachowało do obecnych czasów. Trudno zatem stwierdzić, czy mnisi również w miejscowym kościele mieli możliwość zaznajomienia się z wizerunkiem tronującej Marii z Dzieciątkiem, która mogłaby stać się źródłem inspiracji dla obrazu pieczętnego. W interesującej nas kwestii mamy do dyspozycji tylko wzmiankę o ołtarzu głównym z końca XIII w. noszącym wezwanie maryjne oraz Jana Chrzciciela ${ }^{38}$. Z XIII w. zachował się również iluminowany kodeks wykonany w miejscowym skryptorium. Jest nim Psatterz trzebnicki z pierwszej połowy tego stulecia ${ }^{39}$. Uwage zwraca znana i omawiana w literaturze miniatura przedstawiająca tronującą Marię z Dzieciątkiem w otoczeniu Trzech Króli i Dawida. Stylistyka oraz ikonografia tego przedstawienia, a także innych wizerunków składających się na zespół całostronicowych miniatur, znajduje analogię w środowisku niemieckim (szkoła sasko-turyngska $)^{40}$. Wskazana miniatura nie stała się jednak inspiracją przy tworzeniu wyobrażenia pierwszej pieczęci konwentu - odmienne jest bowiem ukazanie postawy tronującej Marii oraz Dzieciątka, a także detali ich szat. Należy zatem wziąć pod uwagę inne źródło. Moim zdaniem była nim miniatura z graduału lubiąskiego I F 413, który pochodzi z miejscowego skryptorium ${ }^{41}$. Kodeks jest datowany na lata 1320-1330, 1325, 1320-1340 . Barbara Miodońska wskazała podobieństwo dekoracji

32 I.H. Forsyth, The Throne of Wisdom. Wood Sculptures of the Madonna in Romanesque France, Princeton 1972, s. 61-155; H. Belting, Obraz i kult. Historia obrazu przed epokq sztuki, thum. T. Zatorski, Gdańsk 2010, s. 341-342, $442-467$.

33 J. France, The Cistercians in Medieval Art, Stroud 1998, s. 182; J. Nowiński, Ars cisterciensis. Kościót cysterski w średniowieczu - wyposażenie i wystrój, Warszawa 2016, s. 287-297.

${ }^{34}$ Zob. np. P. Bony, An Introduction to the Study of Cistercian Seals. The Virgin as Mediatrix, then Protectrix on the Seals of Cistercian Abbeys, w: Studies in Cistercian Art and Architecture, t. 3, red. M.P. Lillich, Kalamazoo 1987, s. 202, 204, 214-221, po s. 240, fig. 1,4; fig. 6,26, 6,28-fig. 7, 31; fig. 7, 33, 35, 37; fig. 8, 38-39, 41-44; fig. 9, 46, 48-49; fig. 10, 50-55; fig. 11, 56-59; I. Guerreau, Klerikersiegel der Diözesen Halberstadt, Hildesheim, Paderborn und Verden im Mittelalter (um 1000-1500), Hannover 2013, Siegelkatalog, nr G-001, G-020, G-034, G-053, G-070, G-088, G-101, G-113, G-114.

35 Collection des sceaux, t. 3, oprac. L.C. Douët d'Arcq, Paris 1868, s. 26, nr 8308; Sigilla. Base numérique des sceaux conservés en France, <http://www.sigilla.org/fr/sgdb/sceau-type/4408> [dostęp 23.04. 2020].

36 B. Klössel-Luckhardt, Mittelalterliche Siegel des Urkundenfonds Walkenried bis zum Ende der Klosterzeit (um 1578), Göttingen 2017, s. 313-314.

${ }^{37}$ A. Laabs, Malerei und Plastik im Zisterzienserorden. Zum Bildgebrauch zwischen sakralem Zeremoniell und Stiftermemoria 1250-1430, Petersberg 2000, s. 85-86, Abb. 61.

38 R. Kaczmarek, Średniowieczne elementy, s. 32, 35.

39 BUWr., Oddział Rękopisów, sygn. I F 440.

${ }^{40}$ A. Karłowska-Kamzowa, Sztuka Piastów śląskich w średniowieczu. Znaczenie fundacji książęcych w dziejach sztuki gotyckiej na Śląsku, Warszawa 1991, s. 51, 127, ryc. 46; K.K. Jażdżewski, Lubiąż. Losy i kultura umysłowa śląskiego opactwa cystersów (1163-1642), Wrocław 1993, s. 194, 213, 215-219; F. Wolnik, Liturgia ślaskich cystersów w średniowieczu, Opole 2002, s. 183; D. Tabor, Iluminacje cysterskich kodeksów śląskich XIII wieku, Kraków 2004, s. 46-52, 54, 62-65, 82, po s. 155 , il. 54 .

41 BUWr., Oddział Rękopisów, sygn. I F 413.

${ }^{42}$ E. Kloss, Die schlesische Buchmalerei des Mittelalters, Berlin 1942, s. 45-47, 200, Taf. nr 56, 58; A. Karłowska-Kamzowa, Malarstwo śląskie 1250-1450, Wrocław 1979, s. 109-110; taż, Znaczenie iluminatorstwa cysterskiego dla rozwoju gotyckiej 
przede wszystkim do produkcji iluminatorskiej klasztorów cysterskich w Górnej Nadrenii ${ }^{43}$. Zdaniem Dariusza Tabora inicjały zawarte w kodeksie wykazują czeskie, austriackie, południowoniemieckie oraz zapewne francuskie podobieństwa stylistyczne ${ }^{44}$. Przedstawienie $\mathrm{w}$ inicjale $\mathrm{S}($ alve) z przywołanego graduału cechuje taki sam schemat ikonograficzny, jak wizerunek napieczętny (zob. il. 2$)^{45}$. Pomijając drobne różnice w układzie głowy Marii oraz w geście prawej ręki Jezusa, brakuje jedynie mikroarchitektury z wkomponowanymi w nią dwiema figurami. Porównywalna forma architektoniczna występowała w badanym okresie nie tylko na pieczęciach cysterskich, ale także innych dysponentów (np. książęcych), w tym na Śląsku ${ }^{46}$.

Typ Mater Misericordiae (określany również w polskiej literaturze m.in. jako Matka Miłosierdzia lub Matka Boska w płaszczu opiekuńczym) pojawił się najpierw w ikonografii zachodnioeuropejskiej, a ściśle we Włoszech, w drugiej połowie XIII w. na chorągwi rzymskiego bractwa Ricommandati alla Vergine. Motyw ten został zaadaptowany również przez miejscowe zakony żebracze ${ }^{47}$. Wizerunki Matki Miłosierdzia zaczęły się też pojawiać na innych obszarach w pierwszej połowie XIV w. ${ }^{48}$, a rozpowszechniły się od drugiej połowy tego stulecia (m.in. we Francji, Niemczech, Austrii, Hiszpanii, Anglii) ${ }^{49}$. Stosunkowo wcześnie Matka Miłosierdzia była wprowadzana na różne media w kręgu cysterskim ${ }^{50}$. Najstarszym znanym przykładem jest wizerunek wyryty na jednym z guzów nodusa kielicha z opactwa

dekoracji rękopisów na ziemiach polskich (Śląs, Pomorze, Wielkopolska), w: Historia i kultura cystersów w dawnej Polsce i ich europejskie związk, red. J. Strzelczyk, Poznań 1987, s. 370; A. Karłowska-Kamzowa, L. Wetesko, J. Wiesiołowski, Średniowieczna książka rękopiśmienna jako dzieło sztuki, Gniezno 1993, s. 100, nr 33; K.K. Jażdżewski, Lubiaż, s. 190, 214, 223-224; J. Pikulik, Polskie graduały średniowieczne, Warszawa 2001, s. 10; D. Tabor, Malarstwo książkowe na Śląsu w XIV wieku, Kraków 2008, s. 97; F. Wolnik, Liturgia, s. 159-160; R. Kaczmarek, Średniowieczne elementy, s. $46-48$.

${ }^{43}$ B. Miodońska, Śląskie malarstwo książkowe, w: Malarstwo gotyckie w Polsce. Synteza, red. A.S. Labuda, K. Secomska, Warszawa 2004, s. 379.

${ }^{44}$ D. Tabor, Miniatorstwo lubiąskie pierwszej połowy XIV wieku, w: Opactwo cystersów w Lubiązu i artyści, red. A. Kozieł, Wrocław 2008, s. 70-71; tenże, Malarstwo ksiażkowe, s. 92-94, 117-118.

45 BUWr., Oddział Rękopisów, sygn. I F 413, k. 144r.

${ }^{46}$ Na przykład pieczęcie książąt dolnośląskich: Bolesława III legnicko-brzeskiego (piesza IV), Henryka VI wrocławskiego (piesza I oraz II) oraz Henryka II (IV) Wiernego głogowsko-żagańskiego (piesza I) oraz księcia dobrzyńsko-łęczyckiego Władysława (Z. Piech, Ikonografia pieczęci Piastów, Kraków 1993, s. 219-220, nr 37, 225-226, nr 48-49, s. 230, nr 57, s. 235, nr 66), pieczęć konwentu z Łekna (P. Stróżyk, Pieczęcie cysterskie, s. 184, po s. 192, ryc. 1-8) oraz Netley (T.A. Heslop, Cistercian Seals, s. 279, P1. 166).

${ }^{47}$ K.S. Moisan, B. Szafraniec, Maryja orędowniczka wiernych, w: Ikonografia nowożytnej sztuki kościelnej w Polsce, t. 2, red. J.S. Pasierb, Warszawa 1987, s. 10-15; R. Knapiński, Od „Pokrowy” do „Płaszcza opieki”. Przeobrażenia motywu ikonograficznego Mater Misericordiae, „Studia Warmińskie”, 39, 2002, s. 131-142; H. Belting, Obraz i kult, s. 406-413; T. Castaldi, L'iconografia della Madonna della Misericordia e della Madonna delle frecce nell'arte bolognese e della Romagna nel Tre e Quattrocento, „Eikón Imago”, 7, 2015, nr 1, s. 35-37; G. Morello, Od Matki Miłosierdzia do Marii Orantki. Przechadzka wśród twarzy i gestów ikonografii maryjnej, w: Maria Mater Misericordiae, red. P. Krasny, thum. z w1. P. Krasny, A. Lebensztejn, tłum. z ang. Anna Niedźwiedź, Kraków 2016, s. 36-38; A. Zuccari, Matka Boska Miłosierdzia. Początki i przemiany sławnego tematu w ikonografii maryjnej, w: tamże, s. 86-87; Katalog. Strażniczka skarbca Bożego Miłosierdzia w życiu ziemskim i w niebiosach, w: tamże, s. 161; K.T. Brown, Mary of Mercy in Medieval and Renaissance Italian Art. Devotional Image and Civic Emblem, New York 2017, s. 52, 67-77, 107-110, 134-135, 143.

48 Wymienić należy np. dzieło Speculum humanae salvationis znane z rękopisów od pierwszej połowy XIV w.; zob. opis rękopisu datowanego na ok. 1330 r.; B. Hernad, Die gotischen Handschriften deutscher Herkunft in der Bayerischen Staatsbibliothek, t. 1, Wiesbaden 2000, s. 170-176, kat. 249.

49 K.T. Brown, Mary of Mercy, s. 157-169.

${ }^{50}$ Obecnie genezy Mater Misericordiae w ikonografii nie przypisuje się wyłącznie cystersom, jak czyniła to częściowo wcześniejsza literatura; zob. L. Silvy, L'Origine de la Vierge de la Miséricorde, „Gazette des Beaux-Arts”, 34, 1905, s. 401-410; P. Perdrizet, La Vierge de Miséricorde: Étude d'un thème iconographique, Paris 1908, s. 18-27, Pl. II. J. France, The Cistercians in Medieval Art, s. 184, poza powołaniem na cysterską genezę jako najstarszy przykład wskazał omawianą w niniejszym artykule miniaturę z graduału lubiąskiego, którą uznał za wcześniejszą od francuskich pieczęci cysterskich. $\mathrm{Na}$ gruncie cysterskim motyw Matki Miłosierdzia ma korzenie w znanej wizji anonimowego mnicha zawartej w dziele Cezarego z Heisterbach Dialogus Miraculorum z początku XIII w. Aktualnie uznaje się, że ten typ przedstawienia oparty jest na wcześniejszych źródłach; zob. tenże, Cistercians under Our Lady’s Mantle, „Cistercian Studies Quarterly”, 37, 2002 , nr 4, s. 400-401. 
w Wettingen (obecnie w Szwajcarii), datowanego na schyłek XIII w. ${ }^{51}$ Kolejne przedstawienia pochodzą z dwóch francuskich pieczęci konwentualnych z pierwszej połowy XIV w., które należy zaliczyć również do wczesnych ujęć omawianego typu maryjnego z terenu Francji ${ }^{52}$. Są to pieczęć cysterek z Beaupré z datą 1335 w legendzie, znaną z XIX-wiecznego rysunku ${ }^{53}$, oraz pieczęć cystersów z Cercamp zachowaną przy dokumencie z 1352 r. ${ }^{54}$ Pieczęć cysterskiego definitorium z przedstawioną Matką Miłosierdzia jest różnie datowana przez badaczy. Część z nich wskazuje na pierwszą połowę XIV w. ${ }^{55}$, część ogólnie na to stulecie ${ }^{56}$, niekiedy podawane są dokładne daty (ok. $1335 \mathrm{r}^{57}$, ok. $1360 \mathrm{r}^{58}$ ). Statuty kapituły generalnej wskazują jednak, że wymienioną pieczęć wprowadzono dopiero na mocy uchwały z 1390 r. ${ }^{59}$ Powyższe zestawienie pieczęci wskazuje, że w pierwszej połowie XIV w. przedstawienia Matki Miłosierdzia pojawiały się w środowisku cysterskim jeszcze sporadycznie. Większa ich liczba notowana jest dopiero od połowy XIV w. w zachodnioeuropejskich klasztorach cysterskich, ale także w cenobiach na ziemiach polskich (poza pieczęciami są to również freski oraz miniatury w kodeksach) ${ }^{60}$.

Wymienione powyżej przykłady z pierwszej połowy XIV w. nie stały się jednak źródłem drugiej pieczęci konwentu lubiąskiego. Inspiracji dla niej należy szukać w miejscowym klasztorze. W literaturze przedmiotu dostrzeżono już bowiem podobieństwa między pieczęcią konwentu a przedstawieniem w inicjale G(audeamus) z wymienionego już wcześniej graduału IF 413 (zob. il. 4) ${ }^{61}$. Nie przeprowadzono jednak dotąd szerszej analizy obu źródeł ${ }^{62}$. Obraz Matki Miłosierdzia należy zaliczyć bez wątpienia do wczesnych przykładów nie tylko miniatorstwa książkowego, ale także wizerunków tego typu, w tym jest to pierwsze znane przedstawienie tego tematu na ziemiach polskich ${ }^{63}$. Wyobrażenie Matki Miłosierdzia na drugiej pieczęci konwentu odróżnia się nieznacznie od miniatury. Maria nie jest przepasana w talii, odmienne jest połączenie górnej części płaszcza, mniejsza jest również liczba osób pod

${ }^{51}$ J. France, Cistercians under Our Lady's Mantle, s. 402 (datacja kielicha na ok. 1280 r.); K. Siebert, Kelche der ausgehenden Romanik bis zur Spätgotik. Ihre Ikonographie und formale Gestaltung, Göttingen 2015, mps niepublikowanej pracy doktorskiej, <https://d-nb.info/1131354931/34> [dostęp: 16.04. 2021], s. 210, nr 208, s 259, il. 8 a-g (datacja kielicha na ok. 1300 r.).

52 K.T. Brown, Mary of Mercy, s. 52, 106.

53 P. Bony, An Introduction to the Study of Cistercian Seals, s. 223, po s. 240, fig. 11, 60.

${ }^{54}$ Collection des sceaux, s. 8, nr 8174; P. Bony, An Introduction to the Study of Cistercian Seals, s. 202, 221-223, po s. 240, fig. 11, 61 .

55 D. Donadieu-Rigaut, Les ordres religieux et le manteau de Marie, „Cahiers de recherches médiévales et humanistes”, 8, 2001, s. 5-6, doc. 2.

${ }^{56}$ L. Silvy, L'Origine de la Vierge, s. 404; P. Perdrizet, La Vierge de Miséricorde, Pl. II, nr 1, s. 27; S. Solway, A Numismatic Source of the Madonna of Mercy, „The Art Bulletin”, 67, 1985, s. 362-364, nr 10; <http://www.sigilla.org/fr/sgdb/sceautype/4748> [dostęp: 13.06. 2020].

57 K.T. Brown, Mary of Mercy, s. 51-52, fig. 31.

58 P. Bony, An Introduction to the Study of Cistercian Seals, s. 224, po s. 240, fig. 12, 63. Autor odwołał się jednak do drugiego typu, znanego z użycia z początku XVI w. Na te ustalenia powołał się następnie J. France, The Cistercians in Medieval Art, s. 184; tenże, Cistercians under Our Lady's Mantle, s. 405.

${ }^{59}$ Statuta, t. 3, 1318/nr 20, 1334/nr 9, 1390/nr 2; zob. też D.H. Williams, The Cistercians, s. 110; T. Vogtherr, Siegelrecht, s. $72,82-83$.

${ }^{60}$ E. Jamroziak, The Cistercian Order in Medieval Europe 1090-1500, New York 2013, s. 175. Z ziem polskich od połowy XIV w. do schyłku tego stulecia należy wskazać m.in. fresk w kościele klasztornym w Koprzywnicy (A. Karłowska-Kamzowa, Programy ideowe gotyckich malowidet ściennych w Polsce, w: Gotyckie malarstwo ścienne w Europie Środkowo-Wschodniej, red. A. Karłowska-Kamzowa, Poznań 1977, s. 142, il. 2; J. Domasłowski, A. Karłowska-Kamzowa, M. Kornecki, H. Małkiewiczówna, Gotyckie malarstwo ścienne w Polsce, Poznań 1984, s. 36, 323, il. 2; K.S. Moisan, B. Szafraniec, Maryja orędowniczka, s. 16, po s. 171, il. 1; A. Karłowska-Kamzowa, Malarstwo ścienne w Małopolsce, w: Malarstwo gotyckie, s. 94) oraz inicjał figuralny z kodeksu z klasztoru w Kamieńcu (BUWr., Oddział Rękopisów, sygn. I Q 245, k. 230v; K.K. Jażdżewski, Lubiąż, s. 224, przyp. 124).

${ }^{61}$ BUWr., Oddział Rękopisów, sygn. I F 413, k. 145r. Ostatnio D. Tabor wskazał, że omawiana miniatura wykazuje podobieństwo do przedstawienia z graduału z południa Niemiec; zob. tenże, Malarstwo ksiażkowe, s. 94. B. Miodońska dostrzegła ponadto, że źródła kompozycji wizerunku z graduału lubiąskiego należy się doszukiwać w Biblii pauperum. Autorka ta jako przykład podaje kodeks z austriackiego opactwa augustianów w Sankt Florian z ok. 1310 r.; zob. taż, Śląskie malarstwo ksiązkowe, s. 379.

${ }^{62}$ P. Wiszewski, Średniowieczna śląska pieczęć, s. 16; R. Kaczmarek, Średniowieczne elementy, s. 48, 54.

${ }^{63}$ E. Kloss, Die schlesische Buchmalerei, s. 46; A. Karłowska-Kamzowa, Malarstwo śląskie, s. 14; taż, Znaczenie iluminatorstwa cysterskiego, s. 370; taż, Malarstwo ścienne, s. 94; K.K. Jażdżewski, Lubiąż, s. 223-224. 
płaszczem Marii. Zrezygnowano także z przedstawienia konwersów, którzy na miniaturze zostali ukazani w liczbie czterech po lewej stronie Marii. Ponadto na pieczęci na głowie Marii spoczywa korona. Nie zawsze była ona w ten sposób przedstawiana, co potwierdza np. średniowieczne malarstwo z terenu Włoch. Warto również zauważyć, że w przedstawieniach Marii w płaszczu opiekuńczym czasem ujmowano też Dzieciątko; nie było to jednak konieczne, co jest widoczne również w malarstwie włoskim oraz na omawianej miniaturze i pieczęci ${ }^{64}$. Mikroarchitektura na pieczęci także jest inna niż na miniaturze, inspiracji dostarczyła jednak w tym względzie pierwsza pieczęć konwentu. Arkada została dodatkowo wypełniona gwiazdami. Występują one również jako atrybut Marii na obrazach i pieczęciach ukazujących inne typy przedstawień Matki Boskiej ${ }^{65}$.

\section{Przyczyny wymiany wizerunków na pieczęciach konwentu lubiąskiego}

Bezpośrednią przyczyną wprowadzenia wizerunków maryjnych na pieczęcie konwentów była, jak podkreślono wcześniej, uchwała kapituły generalnej z 1335 r. Jednakże to poszczególne wspólnoty decydowały o wyborze konkretnego typu ikonograficznego. Mnisi lubiąscy na pierwszą swoją pieczęć, wykonaną zapewne wkrótce po wspomnianym statucie z 1335 r., wybrali wizerunek tronującej Marii z Dzieciątkiem. Wybór tego tradycyjnego typu ikonograficznego był niewątpliwie podyktowany jego popularnością w sztuce średniowiecznej, w tym na pieczęciach cysterskich, na czele z konwentami w Morimond oraz Pforcie. Zaadaptowanie tego wyobrażenia umożliwiło cystersom podkreślenie królewskiej godności Marii i wpisywało się w ich kult maryjny ${ }^{66}$. Po kilku latach konwent lubiąski zdecydował się jednak na wymianę typariusza. Wpływu na jego zmianę nie miało z pewnością zużycie tłoka. Mało prawdopodobne było także jego zagubienie. W świetle bowiem uchwał kapituły z 1335 i 1336 r. pieczęć konwentu miała być przechowywana w zamknięciu pod kluczem, a dostęp do niej miał być zastrzeżony (podobnie jak zaznaczono to w odniesieniu do pieniędzy klasztornych) dla opata, bursarza, przeora i jednego z mnichów ${ }^{67}$. Druga pieczęć konwentu została zatem wprowadzona z innej przyczyny. Mnisi lubiąscy postanowili bowiem zastąpić dotychczasowy wizerunek nowym tematem. Zmiana ikonografii na pieczęciach nie była odosobniona u cystersów. Tak samo postąpili mnisi z francuskiego opactwa w Cercamp. Pierwsza pieczęć konwentu, która jest znana z odcisku z 1337 r. ${ }^{68}$, została zastąpiona kolejną, poświadczoną w użyciu w 1352 r. Na niej także wprowadzono w miejsce tronującej Madonny wizerunek Matki Miłosierdzia ${ }^{69}$. Przyczyny wyboru Mater Misericordiae na pieczęcie cysterskie, w tym lubiąską, należy moim zdaniem szukać w wymiarze duchowo-społecznym. Mnisi wskazywali zapewne nie tylko na opiekę maryjną nad lokalną wspólnotą (czy w szerszym znaczeniu: nad cystersami), ale także na osobowy charakter wspólnoty (mnisi oraz przewodzący im opat). Wymienione elementy składały się zatem na tożsamość lubiąskich cystersów.

\section{Autorstwo pieczęci konwentu lubiąskiego}

Poza analizą ikonografii, źródeł inspiracji obrazu pieczęci oraz przyczyn wymiany wizerunków na pieczęciach należy poświęcić uwagę autorstwu pieczęci konwentu lubiąskiego. Rozpatrzyć w tym przypadku trzeba nie tylko ikonografię, która, jak wskazałem powyżej, odwoływała się do lokalnych wzorów (miniatur i pieczęci), ale przede wszystkim cechy formalno-stylowe pieczęci. To one pozwalają

${ }^{64}$ K.T. Brown, Mary of Mercy, s. 96.

${ }^{65}$ Tamże, s. 96-97. Na średniowiecznej pieczęci konwentu z Henrykowa, filii lubiąskiej, ukazana została tronująca Maria z Dzieciątkiem na tle ukośnej kratownicy wypełnionej gwiazdami; zob. Praga, Národní archiv, Archiv České koruny, inv. č. 261.

${ }^{66}$ I. Eberl, Cystersi. Historia zakonu europejskiego, tłum. P. Włodyga, Kraków 2011, s. 142-143; J. Nowiński, Ars cisterciensis, s. 285-287.

${ }^{67}$ Statuta, t. 3, 1335/nr 2, 1336/nr 1.

${ }^{68}$ Collection des sceaux, s. 7, nr 8173; P. Bony, An Introduction to the Study of Cistercian Seals, s. 220, po s. 240 , fig. 10, 51.

69 Por. przyp. 54. 
na wskazanie przypuszczalnego pochodzenia autora lub miejsca wykonania typariusza. Należy jednak w tym miejscu zauważyć, że tego typu badania są utrudnione przez potencjał medialny pieczęci, który umożliwiał przenoszenie tych samych rozwiązań ikonograficznych oraz formalno-stylowych na znaczne odległości i przyswajanie ich przez różnych dysponentów pieczęci. W pierwszej kolejności należy zatem rozważyć wykonanie ich we Francji. Kapituła generalna - odbywająca się zwyczajowo w Cîteaux była bowiem miejscem nie tylko podejmowania uchwał w sprawach zakonnych, ale także przepływu informacji oraz kontaktów z osobami świeckimi, np. kupcami ${ }^{70}$. Podczas pobytu opatów lub ich pełnomocników na kapitułach mogła zaistnieć okazja do złożenia zlecenia wykonania tłoka u francuskiego artysty złotnika. Badane pieczęcie nie wykazują jednak cech łączących je z tym terenem. Na marginesie niniejszych rozważań należy stwierdzić, że jak dotąd również dla innych pieczęci cysterskich z ziem polskich nie wskazano cech specyficznych dla francuskiego kręgu kulturowego ${ }^{71}$. Tym samym nie można również na przykładzie pieczęci konwentu lubiąskiego doszukiwać się wpływu artysty złotnika, który mógł przybyć na Śląsk z Francji ${ }^{72}$. W odniesieniu do pieczęci, które odstawały kunsztem od pozostałych, w literaturze przedmiotu wysuwano również inne propozycje. Marian Haisig, a za nim ostatnio Romuald Kaczmarek przypisali niektóre pieczęcie włoskim rytownikom działającym na Śląsku ${ }^{73}$. Obie badane pieczęcie konwentu nie mają jednak cech pozwalających na łączenie ich z południem Europy. Wykazują je za to pieczęcie spotykane w Europie Środkowej ${ }^{74}$, co widoczne jest w stylistyce postaci oraz zastosowanej kompozycji (wpisaniu centralnych postaci $\mathrm{w}$ arkadę, a pozostałych figur w boczne edykuły). Pieczęcie lubiąskie zostały więc moim zdaniem sporządzone najprawdopodobniej w rodzimym warsztacie złotniczym. W pierwszej kolejności należy rozważyć możliwość wykonania typariuszy w klasztorze. W tej kwestii zabrał już głos R. Kaczmarek, nie przesądził jednak sprawy ${ }^{75}$. W zestawieniu przygotowanym przez W.P. Könighausa występuje co prawda w 1362 r. mnich lubiąski Johannes Aurifaber ${ }^{76}$, brak innych źródeł nie pozwala jednak na rozstrzygnięcie tej kwestii. Ośrodkami, w których potencjalnie mogły zostać wykonane pieczęcie, były także miasta śląskie jak Wrocław lub Legnica ${ }^{77}$. Cystersi lubiąscy posiadali w nich od lat 30. XIV w. własne domy ${ }^{78}$. Sprzyjającymi warunkami mogły być również związki z Legnicą wymienionego wcześniej opata Jana II, który pochodził z legnickiej rodziny mieszczańskiej ${ }^{79}$. W badaniu dwóch pieczęci konwentualnych zwraca także uwagę ich zróżnicowany poziom wykonania. Zostały zatem najpewniej wykonane w dwóch różnych warsztatach złotniczych.

70 A. Galar, W europejskiej wspólnocie cysterskiej, s. 453, 456-457.

${ }^{71}$ We Francji jedne z ostatnich badań z zakresu sfragistyki cysterskiej dotyczyły opactwa w Clairvaux. W odniesieniu do tego protoopactwa nie udało się również ustalić, gdzie wykonywano pieczęcie opata i konwentu. A. Baudin ograniczył się do postawienia pytania: „Qu'en est-il du graveur? Fait-on appel à un artisan local ou un orfèvre réputé à Troyes, Châlons, Dijon ou Paris?"; zob. tenże, Sceller à Clairvaux et dans sa filiation champenoise du XII au XV siècle, w: Clairvaux. L'aventure cistercienne, red. A. Baudin, N. Dohrmann, L. Veyssière, Paris 2015, s. 177. W literaturze wysunięto również możliwość powiązania dwóch pieczęci konwentualnych z opactw cysterskich położonych niedaleko Paryża z tym samym atelier, które wykonało pieczęć królowej Nawarry Joanny II; zob. P. Bony, An Introduction to the Study of Cistercian Seals, s. 219-220. Autorstwo projektu pieczęci Joanny II przypisuje się Jeanowi Pucelle. Artysta ten był paryskim iluminatorem rękopisów, a także realizował różnorodne projekty plastyczne (poza pieczęciami m.in. witraże). Na jego twórczość mieli wpływ przedstawiciele włoskiego trecenta oraz sztuka północnego gotyku; zob. K. Gould, Jean Pucelle and Northern Gothic Art. New Evidence from Strasbourg Cathedral, „The Art Bulletin”, 74, 1992, nr 1, s. 51-74; M. Gil, L'enlumineur Jean Pucelle et les graveurs de sceaux parisiens: l'exemple du sceau de Jeanne de France, reine de Navarre (1329-1349), w: Pourquoi les sceaux? La sigillographie, nouvel enjeu de l'histoire de l'art, red. M. Gil, J.L. Chasel, Lille 2011, s. 421-435.

72 Por. M. Gumowski, Pieczęcie śląskie, s. 279-281, 421; Z. Piech, Ikonografia, s. 107.

${ }^{73}$ M. Haisig, Studia nad legenda pieczęci miejskiej, Wrocław 1953, s. 116-117; tenże, Herb miasta Legnicy: jego geneza i symbolika, „Studia Legnickie”, 5, 1969, s. 8-9; R. Kaczmarek, Italianizmy. Studia nad recepcja gotyckiej sztuki włoskiej w rzeźbie środkowo-wschodniej Europy (koniec XIII - koniec XIV wieku), Wrocław 2008, s. 89-101.

${ }^{74} \mathrm{Za}$ spostrzeżenia dotyczące drugiej pieczęci konwentu jestem winien w tym miejscu podziękowania Profesorowi Romualdowi Kaczmarkowi.

75 R. Kaczmarek, Średniowieczne elementy, s. 54.

76 W.P. Könighaus, Die Zisterzienserabtei Leubus, s. 395, nr 297.

77 E. Hintze, Die Breslauer Goldschmiede, Breslau 1906, s. 23-24; tenże, Schlesische Goldschmiede, Breslau 1912, s. $41,43$.

${ }^{78}$ W.P. Könighaus, Die Zisterzienserabtei Leubus, s. 57, 173-190.

79 Tamże, s. 366. 


\section{Podsumowanie}

Wymiana typariuszy konwentu w ciągu kilku lat, z którą spotykamy się w klasztorze cystersów w Lubiążu, nie jest sytuacją typową. Pierwsza z pieczęci jest poświadczona w użyciu w 1341, a kolejna już w 1343 r. W obu przypadkach inspiracją dla obrazu pieczętnego były, jak przypuszczam, miniatury zawarte $\mathrm{w}$ graduale pochodzącym z miejscowego skryptorium z pierwszej połowy XIV w. Cystersi wprowadzili na pierwszej pieczęci szeroko rozpowszechnione w tamtym czasie przedstawienie Madonny tronującej, za to na kolejnej pieczęci zdecydowali się na umieszczenie Mater Misericordiae. Wymiana pieczęci była wynikiem poszukiwań jak najwłaściwszego obrazu służącemu konstruowaniu tożsamości lokalnej wspólnoty (przedstawienie mnichów na czele z opatem w powiązaniu z figurą Marii), a w szerszym zakresie tożsamości cysterskiej, której jednym z kluczowych elementów był kult maryjny. Niewątpliwie atrakcyjny pod względem znaczenia typ Mater Misericordiae dopiero zdobywał swoją pozycję w obszarze różnych mediów w Europie, w tym na pieczęciach cysterskich. Świadczy to o przemyślanej decyzji mnichów lubiąskich i o tym, że wykorzystywali oni pieczęć do kreowania pożądanego przez siebie obrazu własnej wspólnoty. Można zaryzykować również tezę, że jako powtarzalne medium pieczęć lubiąska była jednym z głównych źródeł propagowania przedstawienia Mater Misericordiae na ziemiach polskich. Ikonografia oraz cechy formalno-stylistyczne pieczęci lubiąskich umiejscawiają ich wykonanie w najbliższym regionie. Co prawda ubóstwo źródeł nie pozwala na wskazanie konkretnego warsztatu złotniczego lub autora, ale prawdopodobnym miejscem wydaje się klasztor lub miasta, z którymi związani byli mnisi lubiąscy, jak Wrocław lub Legnica.

\section{Medieval convent seals of the Cistercian monastery at Lubiąż - Chronology, iconography, and the authorship of the seal matrices}

Summary: In the first half of the fourteenth century, in the Cistercian monastery at Lubiąż, there was an exchange of seals after a short time. The first seal is attested in use in 1341, and the next one already in 1343. In both cases, the image on the seal was modelled on, in my opinion, the miniatures from a gradual produced at the local scriptorium in the first half of the fourteenth century. The first seal of the convent depicts a representation of the enthroned Madonna, popular at that time. On the other seal, the monks from Lubiąż put a representation of the Mater Misericordiae. I think that the replacement of the seal was a result of the monastery's decision to use the best possible image (the representation of monks headed by the abbot in connection with the figure of Mary) that would contribute to the construction of their identity and - in a broader sense - the Cistercian identity, one of the chief pillars of which was the Marian cult. Attractive in terms of meaning, the Mater Misericordiae type was just gaining a position on various media in Europe, including the Cistercian seals. This testifies to a well-thought-out decision of the Lubiąż monks and the creation of their desired image through seals. It is also possible to put forward a thesis that, as a repeatable medium, the Lubiąż seal was one of the primary sources of propagating the Mater Misericordiae type of representation in the Polish lands. Based on iconography and formal and stylistic features of the seals of the Lubiąż monastery, it has also been established that they were made in Lower Silesia. The scarcity of sources does not make it possible to indicate a particular goldsmith's workshop or author. Still, the probable place seems to be the monastery or towns with which the Lubiąż monks were associated, like Wrocław or Legnica.

Nota o autorze: Tomasz Kałuski, dr, adiunkt w Instytucie Historii Uniwersytetu Śląskiego w Katowicach. Stypendysta Deutscher Akademischer Austauschdienst (DAAD 2007-2008, 2016) oraz Instytutu Herdera w Marburgu (2010), kierownik grantu Miniatura NCN (2017-2018), profesor wizytujący w Uniwersytecie w Hradec Králové (2021). Zainteresowania badawcze: nauki pomocnicze historii ze szczególnym uwzględnieniem sfragistyki i heraldyki. Obecnie prowadzi badania nad pieczęciami i herbami cystersów na Śląsku od średniowiecza do początku XIX w.

Author: Tomasz Kałuski, PhD, assistant professor at the University of Silesia in Katowice, scholar of the German Academic Exchange Service (DAAD 2007-2008, 2016) and Herder Institute in Marburg (2010), National Science 
Center grant holder (2017-2018), visiting professor at the University of Hradec Králové (2021). His research interests include: the auxiliary sciences of history, especially sphragistics and heraldry. Currently he focuses on the Cistercian seals and coat of arms in Silesia from the Middle Ages to the beginning of the $19^{\text {th }}$ century.

Instytut Historii

Uniwersytet Śląski w Katowicach

ul. Bankowa 11

40-007 Katowice

e-mail: tkaluski@gmail.com

\section{Bibliografia}

Baudin A., Sceller à Clairvaux et dans sa filiation champenoise du XII ${ }^{e}$ au XVe siècle, w: Clairvaux. L'aventure cistercienne, red. A. Baudin, N. Dohrmann, L. Veyssière, Paris 2015, s. 173-183

Belting H., Obraz i kult. Historia obrazu przed epoka sztuki, thum. T. Zatorski, Gdańsk 2010

Bony P., An Introduction to the Study of Cistercian Seals. The Virgin as Mediatrix, then Protectrix on the Seals of Cistercian Abbeys, w: Studies in Cistercian Art and Architecture, t. 3, red. M.P. Lillich, Kalamazoo 1987, s. $201-240$

Brown K.T., Mary of Mercy in Medieval and Renaissance Italian Art. Devotional Image and Civic Emblem, New York 2017

France J., The Cistercians in Medieval Art, Stroud 1998

France J., Cistercians under Our Lady's Mantle, „Cistercian Studies Quarterly”, 37, 2002, nr 4, s. 393-414

Galar A., W europejskiej wspólnocie cysterskiej. Udziat cystersów z historycznych ziem polskich w Kapitułach Generalnych w Cîteaux (XII-XVIII w.), Kraków 2014

Guerreau I., Klerikersiegel der Diözesen Halberstadt, Hildesheim, Paderborn und Verden im Mittelalter (um 1000-1500), Hannover 2013

Kaczmarek R., Italianizmy. Studia nad recepcja gotyckiej sztuki włoskiej w rzeźbie środkowo-wschodniej Europy (koniec XIII - koniec XIV wieku), Wrocław 2008

Kaczmarek R., Średniowieczne elementy wyposażenia i wystroju kościoła klasztornego Wniebowzięcia NMP w Lubiążu. Próba rekonstrukcji, w: Kościót klasztorny Wniebowzięcia NMP w Lubiążu. Historia, stan zachowania, koncepcja rewitalizacji, red. A. Kozieł, Wrocław 2010, s. 31-55

Klössel-Luckhardt B., Mittelalterliche Siegel des Urkundenfonds Walkenried bis zum Ende der Klosterzeit (um 1578), Göttingen 2017

Könighaus W.P., Die Zisterzienserabtei Leubus in Schlesien von ihrer Gründung bis zum Ende des 15. Jahrhunderts, Wiesbaden 2004

Nowiński J., Ars cisterciensis. Kościót cysterski w średniowieczu - wyposażenie i wystrój, Warszawa 2016

Stróżyk P., Pieczęcie cysterskie z opactwa w Łeknie-Wagrowcu (cz. I), „Studia i Materiały do Dziejów Pałuk”, 4, 2003, s. 179-202

Tabor D., Malarstwo ksią̇kowe na Ślasku w XIV wieku, Kraków 2008 


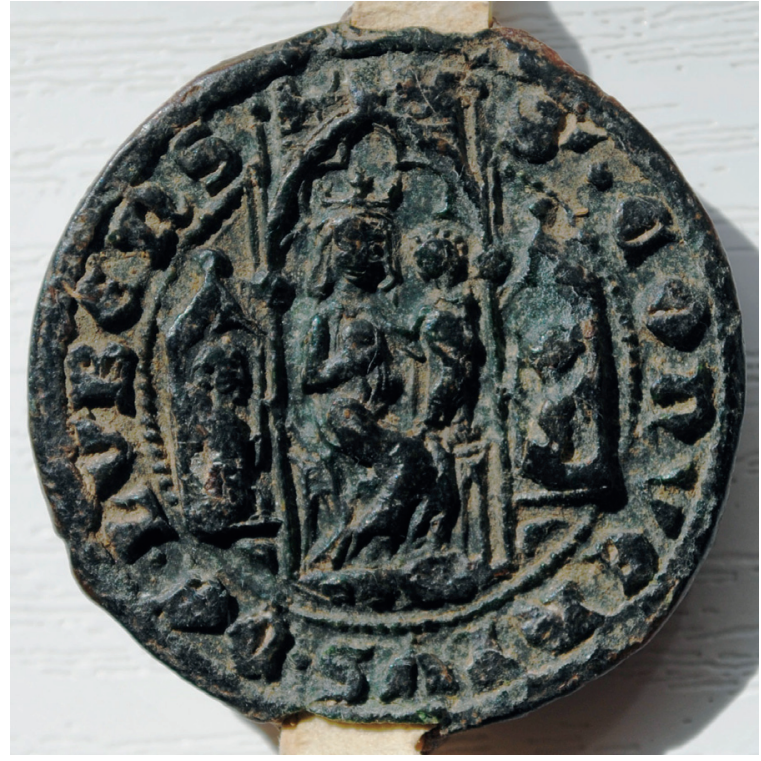

I1. 1. Pieczęć konwentu I w Lubiążu; AP Wrocław, Rep. 125, nr 186 b (odcisk pieczęci z 1341 r.)

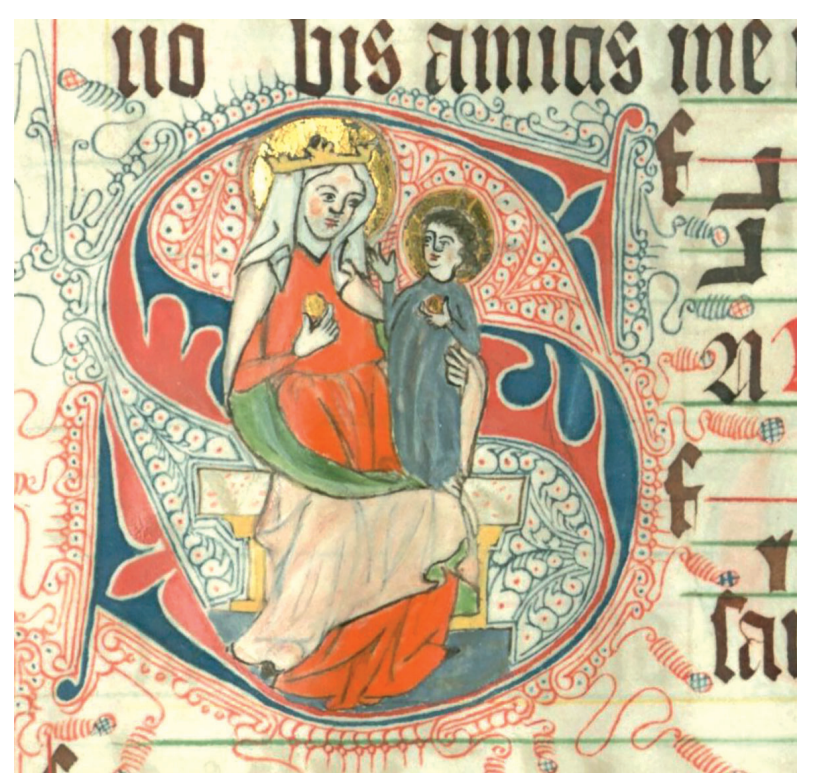

Il. 2. Graduał lubiąski, inicjał S(alve); BUWr., Oddział Rękopisów, sygn. I F 413, k. 144r (pierwsza połowa XIV w.)

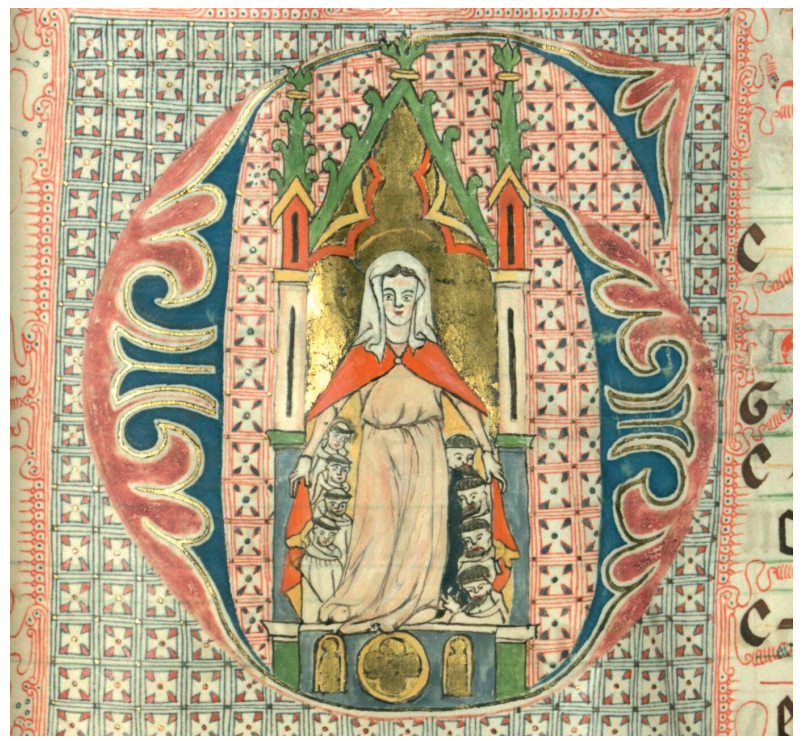

Il. 4. Graduał lubiąski, inicjał G(audeamus); BUWr., Oddział Rękopisów, sygn. I F 413, k. 145r (pierwsza

połowa XIV w.)
Il. 3. Pieczęć konwentu II w Lubiążu; AP Wrocław, Rep. 91, nr 292 (odcisk pieczęci z 1343 r.)

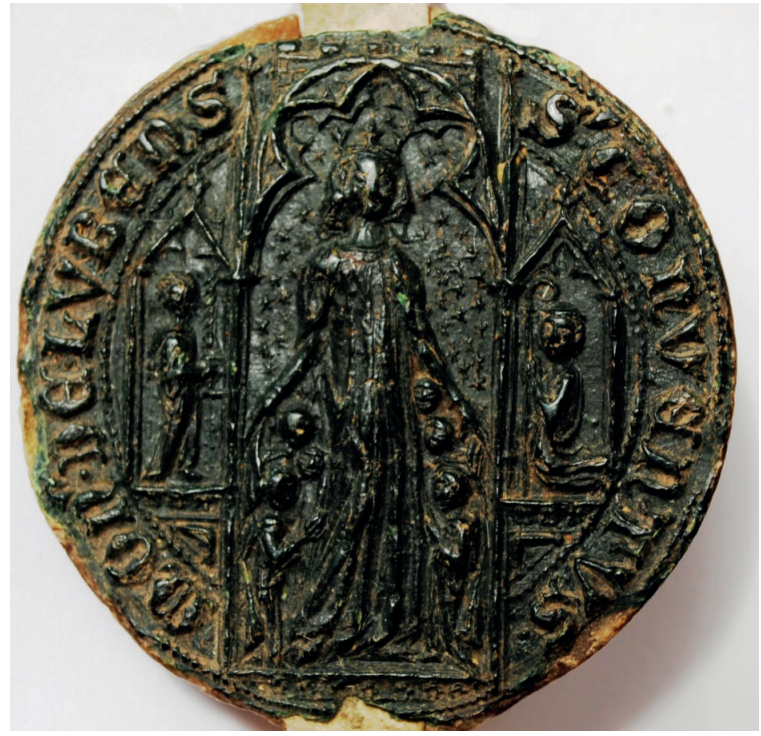



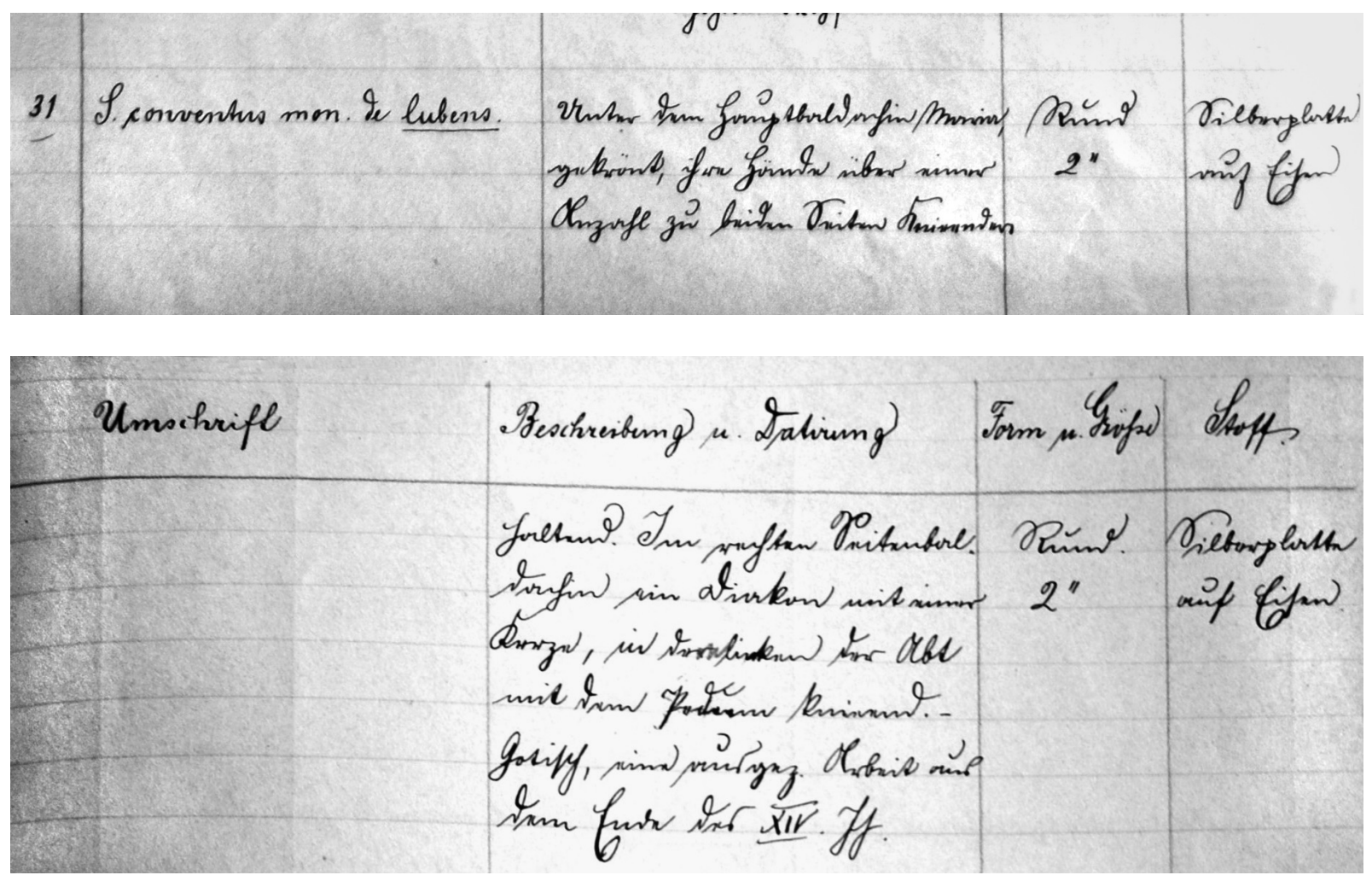

Il. 5-6. Opis archiwalny pieczęci konwentu II w Lubiążu; AP Wrocław, Kolekcja rękopisów Oddziału I, sygn. 369 (koniec XIX w.) 